\title{
HYDROLOGIC EFFECTS OF PROPOSED CHANGES IN UANAGEMENT PRACTICES, WINNEBAGO POOL, WISCONSIN
}
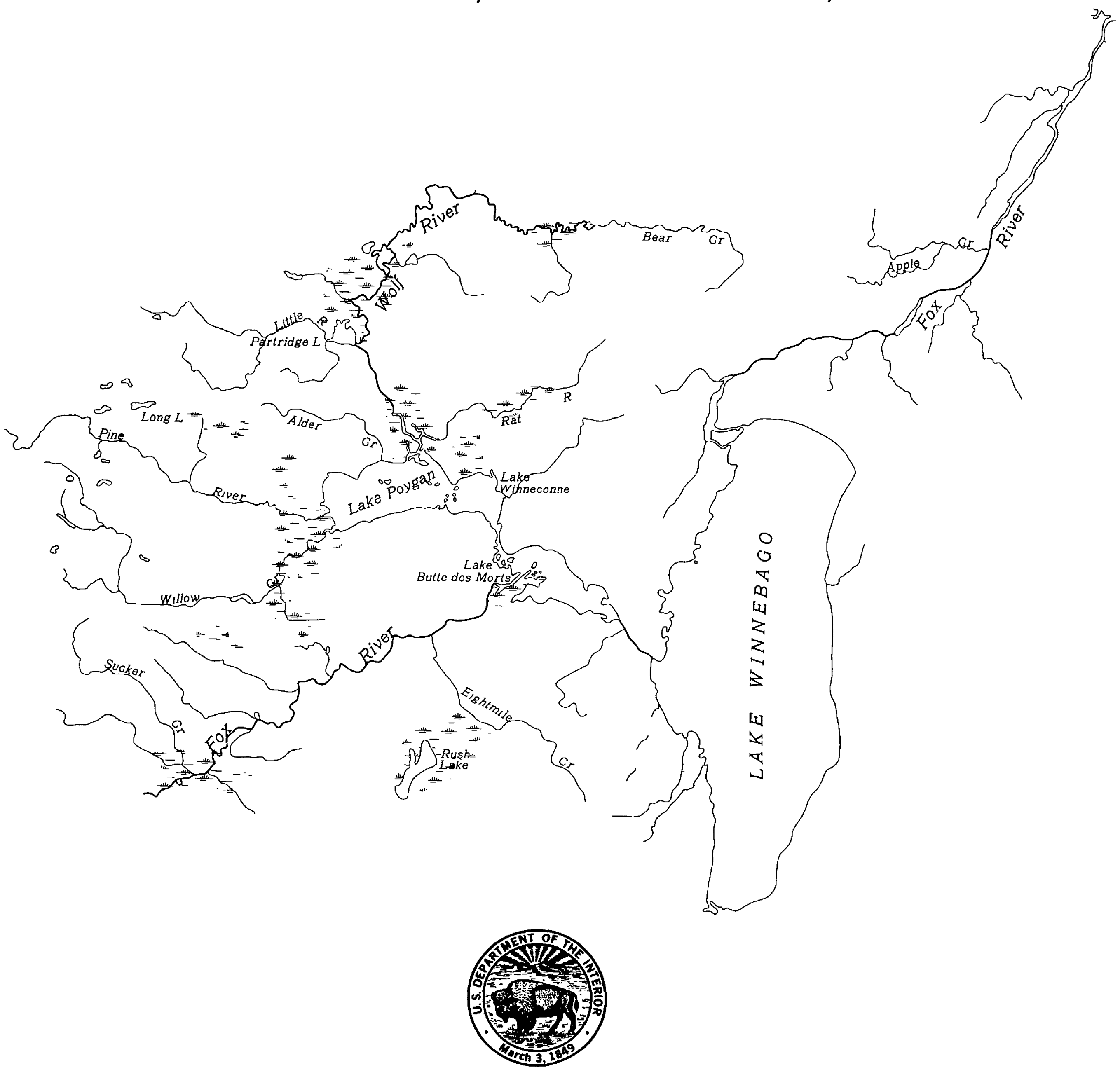

PREPARED BY

UNITED STATES DEPARTMENT OF THE INTERIOR

GEOLOGICAL SURVEY

IN COOPERATION WITH

WISCONSIN DEPARTMENT OF NATURAL RESOURCES

FOX VALLEY WATER QUALITY PLANNING AGENCY 


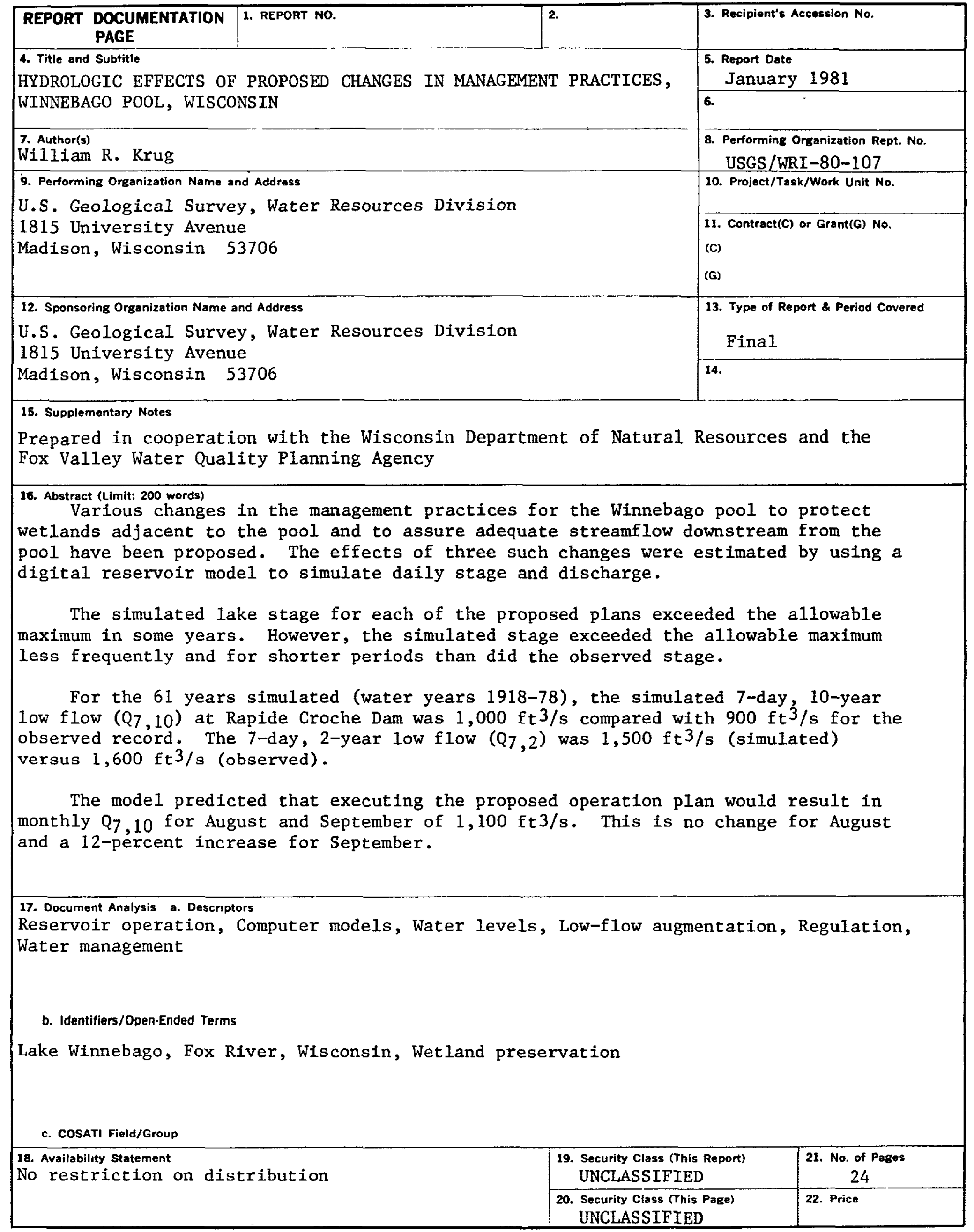




\section{HYDROLOGIC EFFECTS OF PROPOSED CHANGES IN MANAGEMENT PRACTICES, WINNEBAGO POOL, WISCONSIN}

WILLIAM R. KRUG

\section{U.S. GEOLOGICAL SURVEY}

WATER-RESOURCES IN VESTIGATIONS 80-107

Prepared in cooperation with the

Wisconsin Department of Natural Resources and

Fox Valley Water Quality Planning Agency

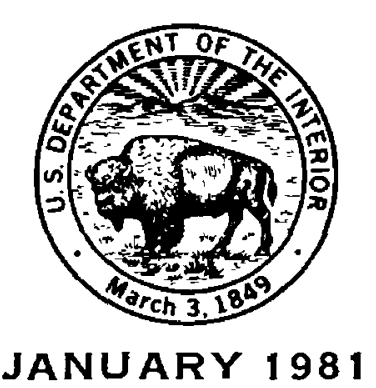




\section{UNITED STATES DEPARTMENT OF THE INTERIOR}

CECIL D. ANDRUS, SECRETARY

\section{GEOLOGICAL SURVEY}

H. William Menard, Director

For additional information write to:

U. S. Geological Survey

1815 University Avenue

Madison, Wisconsin 53706 
$\underline{\text { Page }}$

Abstract--_-_--_-_-_-_-_- 1

Int roduction--

Flow and water-level modeling-_ 5

Inflow computation-_- 5

Pool-level control model-_-_- 7

Rules proposed for wetland protection-_-_-_-_-_-_-_-_ 7

Model constraints on discharge and stage-_._- 8

Method of stage and discharge computation-_._- 10

Outflow determination-_- 10

Storage routing-_- 11

Routing to Wrightstown, Wis.-- 11

Results of proposed operation Plans A and B-_ 11

Change in low flow- 11

Changes in flood peaks- 13

Changes in stage-_-__- 14

Reduction in maximum stage-_. 16

Feasibility of implementing the proposed plans---_-_-_----- 16

Results of proposed operation Plan C-_- 16

Maintaining minimum discharge-_- 16

Summary--_- 18

References-- 19

\section{ILLUSTRATIONS}

$\underline{\text { Page }}$

Figure 1. Map showing location of Winnebago pool in Wisconsin--.--_- 2

2. Location of lakes included in the Winnebago pool-_.....- 3

3-11. Graphs showing:

3. Comparison of inflow to the Winnebago pool computed by two different methods: 1 . Net inflow computed from outflow and change in storage. 2. Surface inflow computed from gaging stations upstream-----

4. The maximum and minimum discharges possible at any

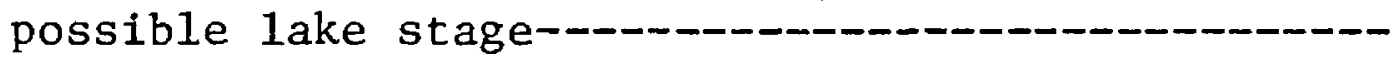

5. The variation of the preferred range of stage for the Winnebago pool during the year, according to Plan B--

6. Comparison of 7-day, low-flow frequency curves for the Fox River near Wrightstown (04084500) for water years 1918-78-_-

7. Comparison of 7-day, low-flow frequency curves for the Fox River near Wrightstown (04084500) for water years 1948-78--

8. Comparison of high-flow frequency curves for the Fox River near Wrightstown (04084500)-_- 
9. Comparison of mean monthly stages of the Winnebago pool for water years 1918-78-_-_-

10. Comparison of observed stage of the Winnebago poo1 with stage simulated for Plan B for two recent years, one very wet (1973), and the other very dry (1976) - -

11. Lowest stage during navigation season for various levels of minimum discharge maintained in the Fox River-_-

\section{CONVERSION TABLE}

For the use of readers who prefer the International System of Units (SI) rather than inch-pound units, the conversion factors for the terms used in this report are listed below.

\section{Multiply}

cubic foot per second $\left(f t^{3 / s}\right)$

foot $(f t)$

inch
By

$2.832 \times 10^{-2}$

0.3048

25.4
To obtain

cubic meter per second $\left(\mathrm{m}^{3}\right)$

meter (m)

millimeter (mm) 


\title{
HYDROLOGIC EFFECTS OF PROPOSED CHANGES IN MANAGEMENT PRACTICES, WINNEBAGO POOL, WISCONSIN
}

\author{
WILLIAM R. KRUG
}

\begin{abstract}
Various changes in the management practices for the Winnebago pool have been proposed. The objectives of the proposed changes are protecting wetlands adjacent to the lakes in the pool and assuring adequate flow in the Fox River downstream from Lake Winnebago. Three proposed operation plans for the Winnebago pool were studied to determine the effects on lake stage and discharge. A digital reservoir model simulated daily lake stage and discharge from the Winnebago pool.

Inflow for this simulation was computed from daily discharge, recorded at Rapide Croche Dam, and daily stage, recorded at Oshkosh. This computed inflow is net inflow, combining the effects of streamflow, precipitation, evaporation, and net ground-water inflow.

The model was adapted to simulate operation of the Winnebago pool according to each of the proposed plans. Because the important features of each operation plan were expressed in terms of stages to be attained at certain dates, simulated discharge was adjusted daily to keep simulated lake stage close to that specified in the plan.

The simulated lake stage for each of the proposed plans exceeded the allowable maximum in some years. However, the simulated stage exceeded the allowable maximum less frequently and for shorter periods than did the observed stage.

For the 61 years simulated (water years 1918-78), the simulated 7-day, 10year low flow $(Q 7,10)$ at Rapide Croche Dam was $1,000 \mathrm{ft}^{3} / \mathrm{s}$ compared with $900 \mathrm{ft}^{3} / \mathrm{s}$ for the observed record. The 7-day, 2-year low flow $\left(Q_{7}, 2\right)$ was $1,500 \mathrm{ft} 3 / \mathrm{s}$ (simulated) versus $1,600 \mathrm{ft}^{3} / \mathrm{s}$ (observed).

The model predicted that executing the proposed operation plan would result in monthly $Q_{7}, 10$ for August and September of $1,100 \mathrm{ft} / \mathrm{s}$. This is no change for August and a 12 -percent increase for September.
\end{abstract}


In addition, the study illustrated that the discharge from the Winnebago pool could be managed to guarantee that the discharge in the Fox River downstream would not fall below a specified discharge up to $1,500 \mathrm{ft} 3 / \mathrm{s}$. In most years this would have no effect on the stage of the pool. In a few years there would be a conflict between releasing water from the pool to maintain the desired discharge and maintaining water levels above the required minimum stage. The frequency of this possible conflict varies with the level of discharge desired in the Fox River--from 1 year in 60 for a discharge of $1,100 \mathrm{ft} 3 / \mathrm{s}$ to about 1 year in 15 for a discharge of $1,500 \mathrm{ft}^{3} / \mathrm{s}$.

\section{INTRODUCTION}

The Winnebago pool and the lower Fox River are in east-central Wisconsin (fig. 1). The pool consists of four major lakes (Winnebago, Butte des Morts, Winneconne, and Poygan) and parts of two rivers (the upper Fox River and the Wolf River) (fig. 2). The surface elevation of all these bodies of water is controlled by two dams at the twin outlets of Lake Winnebago. The Menasha Dam is controlled by the Corps of Engineers and the Neenah Dam is owned and operated by the Neenah-Menasha Power Co.

Water levels in the pool are regulated by the Corps of Engineers in accordance with the River and Harbor Act of 1894, as presented in the NCCED-H Master Reservoir Regulation Manual dated November 1979. During the navigation season (currently considered to be May 1-0ctober 31), the water level is to be maintained between the crest of the dams and $1.77 \mathrm{ft}$ above the crest, if possible. During the winter, water levels may be lowered as much as $1.5 \mathrm{ft}$ below the crest of the dams. During the winter, water levels are normally lowered below the dam crests to prevent ice damage along the lake shores and to be prepared for spring runoff. During the spring runoff, the water level normally rises to near the maximum allowed level, reducing flood discharges in the lower Fox River. During the navigation season, the water level fluctuates in response to changing inflow. Normally the level tends to be lowered as the season progresses, but is still above the dam crests at the end of the navigation season.

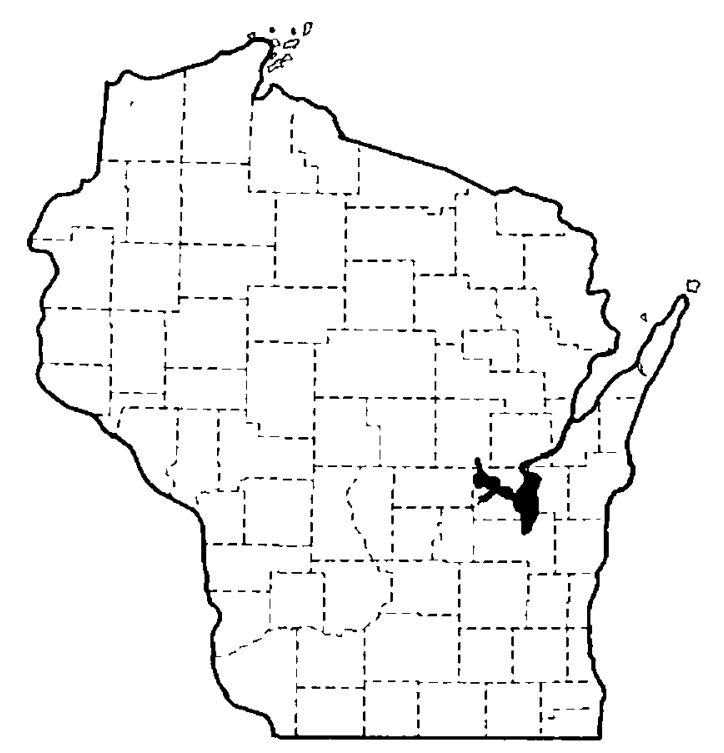

Figure 1. Location of Winnebago pool in Wisconsin. 


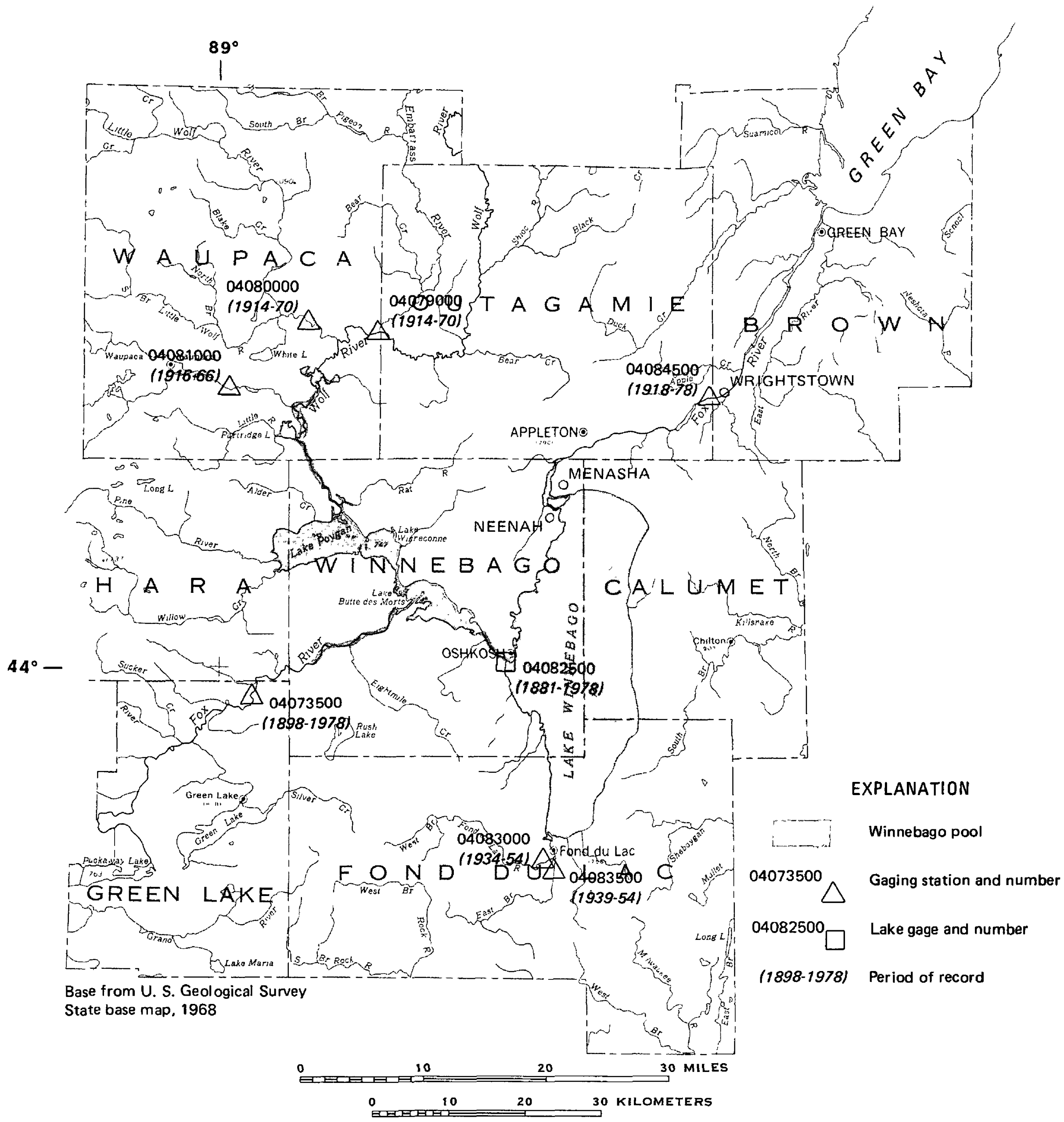

Figure 2. Location of lakes included in the Winnebago pool. 
The Fox River downstream from the outlet of Lake Winnebago is heavily used by municipalities and industries for waste disposal. If changes in water-level management of the Winnebago pool were to reduce low flows of this reach of the Fox River, it could have serious effects on water quality. Higher level treatment of municipal and industrial waste water could also be required to attain waterquality standards.

Wetlands adjoining the lakes of the Winnebago pool have been progressively destroyed by high water levels, ice, and wave action during the past 130 years. Historical records document large losses of wetland associated with exceptionally high water (Arlin Linde, DNR, written commun., 1979). Modifications to the stage-management practices of the Winnebago pool have been proposed by the Wisconsin Department of Natural Resources. The intent of the proposal is to prevent further destruction of wetlands, if possible, without significantly affecting other uses of the Winnebago pool.

Damage to wetlands is greatest when ice that is frozen solidly to the vegetation is lifted by rapidly rising water during the spring. This uproots the vegetation and exposes the underlying soil to erosion by wave action. The erosion deepens the water body and prevents reestablishment of vegetation. Further damage is caused by excessively high water levels in spring and summer and by rapid fluctuations in water level during the growing season. The proposed operations are intended to reduce the frequency of conditions causing the loss of wetlands. Specifically, the proposal calls for:

1. Lowered water levels in the winter to prevent buildup of ice in the wetlands.

2. Delayed filling of the pool in spring until after the ice breaks up to prevent the lifting of ice on the wetlands.

3. Stable water levels in June to prevent damage to growing aquatic vegetation.

To determine the effects of these proposed operating plans on flows in the lower Fox River, a digital model was used to simulate operation of the Winnebago pool water levels.

The discharge capacities of the dams at all stages are included in the model--it will not simulate a release greater than the capacity of the dams with all gates open or less than the capacity of the spillways with all gates closed. Within the constraints imposed by the dam capacities, the model will maintain the pool stage within the legal limits, if possible.

This study was done by the U.S. Geological Survey in cooperation with the Wisconsin Department of Natural Resources (DNR) and the Fox Valley Water Quality Planning Agency (FVWQPA). The purpose of the study is to simulate the operation of the Winnebago pool according to three similar proposed Plans A, B, and C, described subsequent1y. This simulation will provide the data to determine the effects of operation according to these plans on pool stage and on low flows in the Fox River downstrean from the pool. 


\section{FLOW AND WATER-LEVEL MODELING}

The steps involved in this study were as follows:

1. Inflow to the Winnebago pool for 61 years was computed from records of outflow and stage.

2. A digital model was developed to simulate regulation of the Winnebago pool for three proposed operating plans. This model simulated daily stage and outflow from the pool for each of the three plans.

3. The low flows, high flows, and pool stages from the simulation for each plan were compared with observed low flows, high flows, and pool stages for the same period to determine the effects of regulating the Winnebago pool according to the proposed plans.

\section{INFLOW COMPUTATION}

Daily inflow to the Winnebago pool was required to simulate the results of the proposed operation plan. There are streamflow gaging stations on several of the major tributaries to the Winnebago pool (fig. 2), but these have varying periods of record and do not measure the total surface-water inflow. Furthermore, the gaging stations provide no information about ground-water contributions to the Winnebago pool or about the evapotranspiration from the pool. Therefore, to account for all of the factors affecting inflow to the Winnebago pool, net inflow was computed from measured outflow for the Winnebago pool and the change in stage in the pool.

Stage of the Winnebago pool is recorded at Oskhosh, at about the middle of the west side of Lake Winnebago $(04082500$, fig. 2). The stage record shows significant fluctuations in stage, which seem to be caused by wind setup and by seiches caused by changes in wind and in barometric pressure. Thus changes in stage, as measured at this gage, do not reflect changes in storage in the poo1 accurately. Before this record could be used to compute inflow to the pool, fluctuations due to wind and seiches had to be removed. Fluctuations of only $0.05 \mathrm{ft}$ in stage would produce errors of more than $4,000 \mathrm{ft}^{3} / \mathrm{s}$ in the computed discharge.

The stage data were edited and smoothed in two steps. First, the record was edited to correct stages greatly affected by the wind. Any daily stage value that was different from the average of the day before and the day after by more than $0.05 \mathrm{ft}$ was changed to equal that average. This corrected stages that were obviously affected by wind. It also corrected records for a few days when data were obviously in error or missing.

The second step was taking a 7-day weighted moving average. In this averaging, the center day of the average was given more weight than the days before or after. Specifically, the center day of the seven was given a weight of 4 , the preceding and following days were given a weight of 3 , the next preceding and following days 2, and the first and last day 1 . This weighting of the average kept the general shape of the stage hydrograph, while smoothing the day-to-day variations.

After the stage record was smoothed and edited, it was used to compute daily change in storage in the pool. A stage-storage relation determined by the 
Corps of Engineers (unpublished data, 1922) was used. This relation was checked by comparing areas for the water surface and the first topographic contour above the water surface on recent topographic maps. No significant differences could be found.

To determine net inflow, it was necessary first to determine outflow. The streamflow record for the Fox River at Rapide Croche Dam near Wrightstown, Wis., (04084500, fig. 2) was adjusted to represent outflow from the Winnebago pool by allowing 1 day for the time it takes a change in discharge to travel from the outlet of Lake Winnebago to Rapide Croche Dam. This time will vary with discharge and with changes in operation at the dams in-between. One day is an average for all these variable conditions. No adjustment was made for inflow between Lake Winnebago and the gaging station because the difference in drainage area is less than 2 percent, and no reasonable estimate for the ungaged inflow from this area could be determined.

The daily change in storage was added algebraically to the outflow from Lake Winnebago to determine the net inflow to the pool. This net inflow is the sum of surface-water inflow, ground-water inflow, and precipitation minus evapotranspiration and ground-water outflow. At times of high runoff, the net inflow is almost entirely surface-water inflow. During some dry periods in summer, the net inflow is negative because evapotranspiration from the pool exceeds all other inflows.

The computed net inflow was checked by comparing it with the sum of streamflow recorded at six gaging stations (fig. 2) on streams upstream from the pool. Discharge recorded at these gaging stations was routed to the pool and multiplied by a drainage-area ratio to account for ungaged inflow. This agreed very closely with the net inflow for periods of significant surface runoff. A typical example of this comparison is shown in figure 3. The difference during the periods of

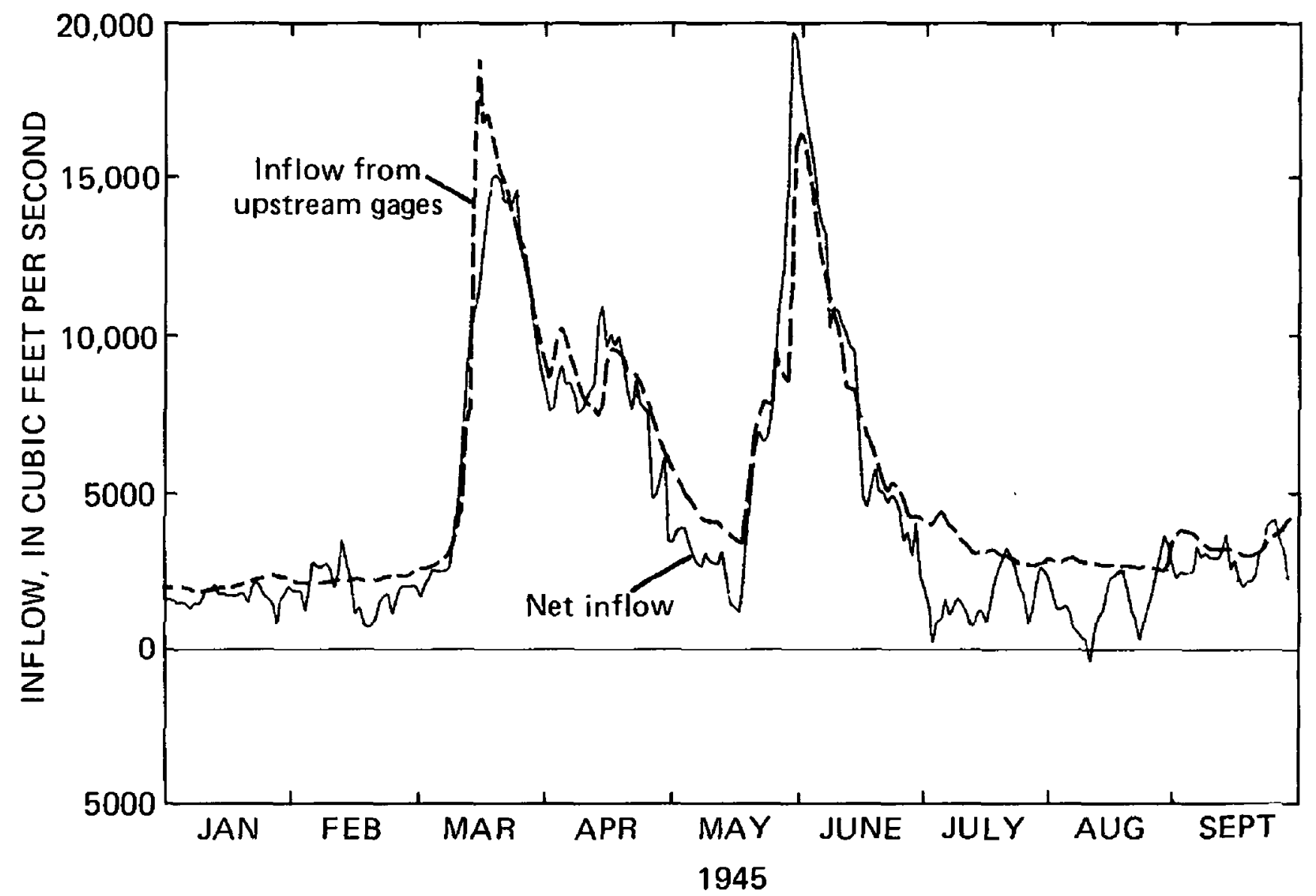

Figure 3. Comparison of inflow to the Winnebago pool computed by two different methods: 1. Net inflow computed from outflow and change in storage.

2. Surface inflow computed from gaging stations upstream. 
higher discharge may be explained by nonuniform runoff from the ungaged part of the drainage basin. In the case of the peak around June 1 , the net inflow includes the effect of rain falling on the pool itself, which is not accounted for in routing the flows from stream gages. During the summer, the net inflow was frequently less than the routed inflow. The difference was about the same as that to be expected from evapotranspiration from the surface of the pool.

The gaged inflows were routed to the reservoir by the unit-response concept and convolution technique described by Sauer (1973), with the unit-response functions computed by the diffusion-analogy method (Keefer, 1974). The computations were done by computer programs developed by the U.S. Geological Survey (Shearman and others, written commun., 1979).

The streamflow routing could not be calibrated because there is no direct measure of inflow with which to compare the routed inflow. The similarity of the routed inflow with the computed net inflow supports the adequacy of the computed net inflow for use in the reservoir simulation.

The routed inflow was not used in the reservoir simulation for several reasons:

1. Several of the tributary gages used in the routing had periods of record that were too short for an adequate simulation of reservoir operations.

2. The routed inflow does not include direct precipitation on the pool or evaporation from the pool.

3. The routed inflow includes an estimate for 23 percent of the drainage area, based on the flow measured at other locations.

\section{POOL-LEVEL CONTROL MODEL}

The model is used to simulate water level in the pool and discharge from the pool for each of the three proposed operation plans. Plans A and B are intended to reduce damage to wetlands. These two plans differ slightly in the timing of drawdown and refilling of the pool. They are explained in more detail in the following section. Plan $C$ is a modification of Plan B and guarantees that a certain minimum discharge will be maintained at all times. Plan $C$ is explained in a later section.

\section{Rules proposed for wetland protection}

For Plan A, the rules used to guide the water-level control model are in the form of stage levels to be met on certain dates as follows:

1. Beginning on November 1, the pool is to be lowered gradually to the dam crest elevation ( $1.68 \mathrm{ft}$ on the gage at Oshkosh) by December 31 .

2. The drawdown is continued to reach a level 1 to $1.5 \mathrm{ft}$ below the crest ( 0.68 or $0.18 \mathrm{ft}$ on the gage at Oshkosh) about March 15. The minimum level is $1.5 \mathrm{ft}$ below the crest if there is more than $1 \mathrm{ft}$ of snow on the ground on February 15, otherwise the minimum level is $1 \mathrm{ft}$ below the crest. 
3. After March 15, the pool level is to be gradually raised to the crest elevation by April 30 and to a stage of about $3.0 \mathrm{ft}$ on the gage at Oshkosh by early June.

4. From June through October, the stage is to remain constant or slowly decline (depending upon inflow) but always remain above the crest.

For Plan B the rules listed for Plan A are modified as follows:

1. The same as Plan A.

2. The minimum water level is to be reached by March 1 instead of March 15, otherwise this is the same as Plan A.

3. After March 15, the pool level is to be gradually raised to reach the crest elevation by April 30. This rule is followed only until ice breakup. After breakup, the water level in the pool is allowed to rise rapidly to a stage of $3.0 \mathrm{ft}$ if inflow is sufficient. After breakup, rule 3 from Plan $A$ is taken as the minimum water level to be allowed if there is little inflow.

4. The same as Plan A except that stage should be held constant, if possible, through June, then allowed to decline slowly through October.

These proposed rules differ from recent operations in three main aspects:

1. The fall and winter drawdown for the proposed plans normally is greater than it has been during actual operations.

2. The proposed rules delay the spring filling as much as possible, until ice breakup; actual operations allow the pool to rise with the spring flood, whenever it occurs.

3. The proposed rules seek a maximum stage in early summer of $3.0 \mathrm{ft}$ (unless a higher stage is required by high inflow), whereas actual operations have maintained stages greater than $3.0 \mathrm{ft}$ in some years.

\section{Model constraints on discharge and stage}

For the plan to be attainable, it must conform to certain limits. Constraints were included in the model for discharge and stage, as determined by legal restrictions and by the physical capacity of the outlet dams. The regulatory stage limits are 1.68 to $3.45 \mathrm{ft}$ from May 1 through October 31 and 0.18 to $3.45 \mathrm{ft}$ for the rest of the year.

Rating curves for the outlet dams were obtained from the Corps of Engineers (written commun., 1979). These curves were checked against the historical records to determine the maximum and minimum discharge that could be allowed for any given stage. The maximum discharges observed for each stage compared very closely with the rating curve for the spillways plus all gates. This rating 
curve defined maximum discharge to be allowed at any stage. The minimum historical discharges for each stage were somewhat greater than those given by the rating curve for the spillways. The model used a rating curve that approximated the minimum historical flows for each stage for its minimum discharge constraint. The two rating curves defining maximum and minimum possible discharge for use in the model are shown in figure 4.

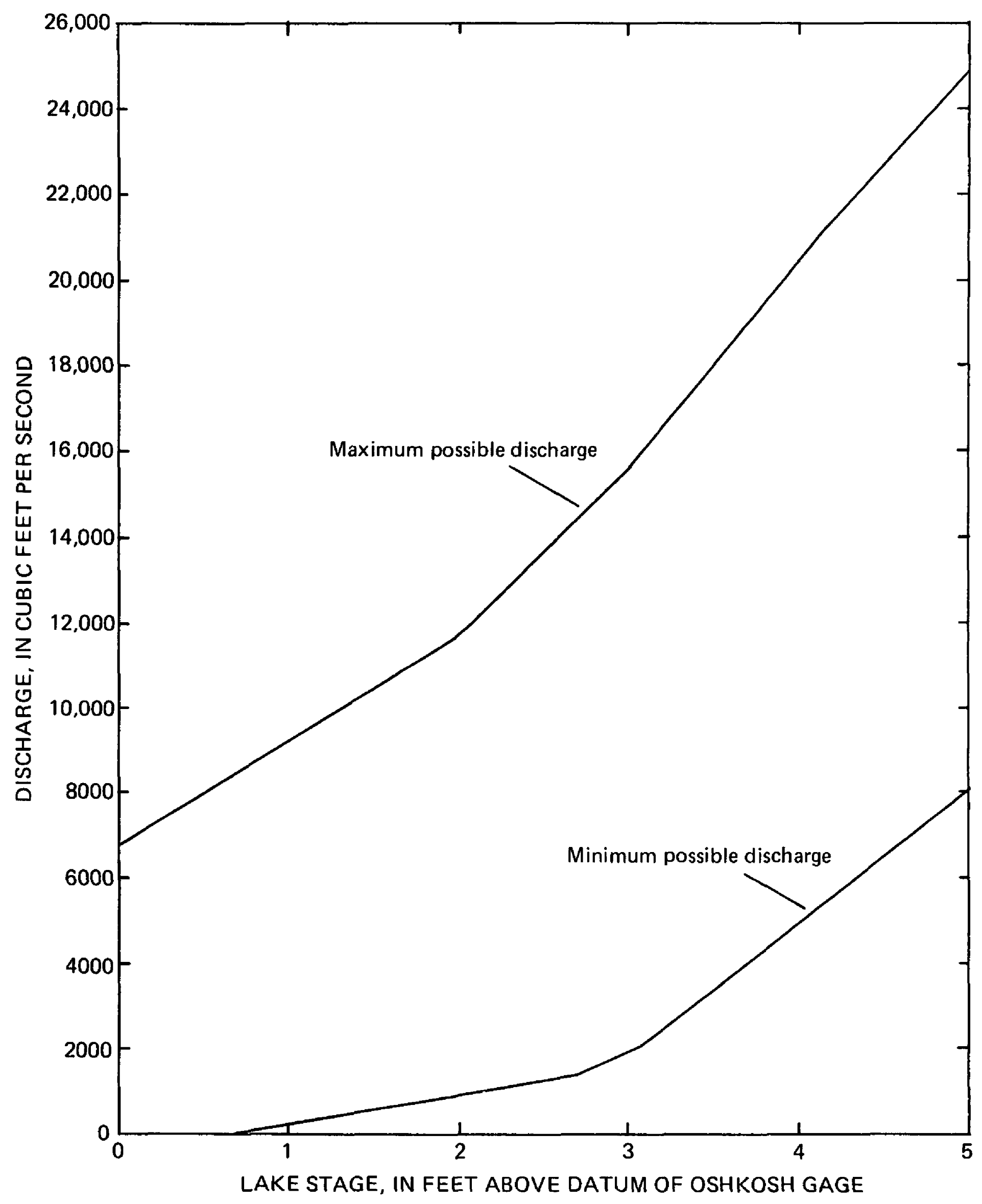

Figure 4. The maximum and minimum discharges possible at any possible lake stage. 
The regulatory limits of allowable stage and the preferred range in stage according to P1an B through the year are shown in figure 5. This graph shows the seasonal stage variation for the second version of the proposed operation. The graph shows two options for the upper limit of the preferred range in spring, depending on the date of breakup. In each year, the actual upper limit will depend on the date of breakup and will be between the two extremes shown. The graph also shows a wide preferred range in February and March depending on the amount of snow on the ground. With little snow on the ground, the preferred stage is near the upper limit of the range shown, and, with more than $1 \mathrm{ft}$ of snow on the ground, the preferred stage is near the lower limit of the range shown.

\section{Method of stage and discharge computation}

Outflow Determination.--For all three plans, the model determines daily outflow from four factors:

1. the computed stage at the end of the preceding day

2. the day of the year

3. the quantity of snow on the ground (used only between February 15 and April 30)

4. whether the ice has broken up (used only during the period when breakup is possible)

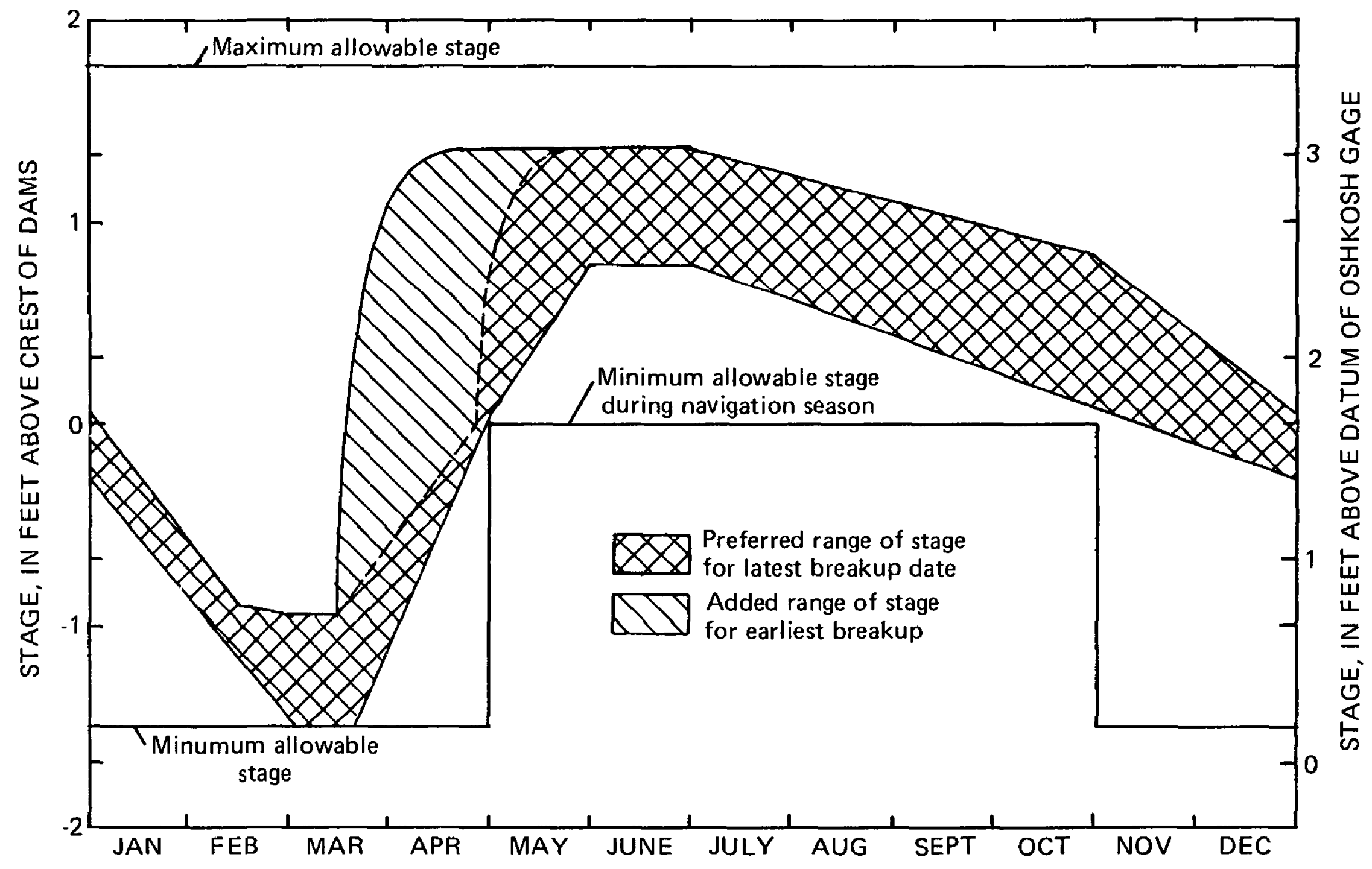

Figure 5. The variation of the preferred range of stage for the Winnebago pool during the year, according to Plan B. 
The last three factors are used to determine the target or preferred stage as specified by the proposed plan. The range of preferred stage for Plan B is shown on figure 5 for an entire year. The computed outflow is larger for higher stages than for lower stages. If the stage is within the preferred range, the model computes an outflow between 1,100 and $4,000 \mathrm{ft}^{3} / \mathrm{s}$. The model computes a large outflow (between $4,000 \mathrm{ft}^{3} / \mathrm{s}$ and the maximum possible), if stage is above the preferred range, and a small outflow (between $1,100 \mathrm{ft}^{3} / \mathrm{s}$ and the minimum possible) if stage is below the preferred range. The simulated outflow is computed by interpolating between the specified discharges, based on the computed stage at the end of the preceding day.

The model does not determine the gate openings required to produce the computed outflow. It is assumed that some combination of gate openings could be made to actually release the discharge computed by the model. The model will never compute a discharge greater than the one that would be released with all gates open or less than the one that would flow over the spillway with all gates closed.

Storage Routing.--Each day, after the outflow is computed as described above, the net inflow is added to the storage in the pool and the computed outflow is subtracted. This gives the end-of-day storage in the pool. From this, the endof-day stage is determined from the same stage-storage table that was used to compute the net inflow.

Routing to Wrightstown, Wis.-The computed outflow from the Winnebago pool is lagged 1 day to approximate the traveltime to Wrightstown. This lagged outflow is the simulated flow for the Fox River at Wrightstown.

\section{RESULTS OF PROPOSED OPERATION PLANS A AND B}

\section{Change in low flow}

The 7-day low-flow frequency curves were computed from the simulated streamflow for both Plans A and B for the Fox River near Wrightstown for October 1917-September 1978 and for observed discharges for the same period. The curves are shown in figure 6 . The annual minimum 7-day mean flows below which the flow will fall on the average every 2 and 10 years $\left(Q_{7,2}\right.$ and $Q_{7}, 10$, respectively) are compared in the following table.

$$
\text { Comparison of simulated and observed } Q_{7,2} \text { and } Q_{7,10}
$$

for the Fox River at Rapide Croche Dam near Wrightstown

\begin{tabular}{cccccc}
\hline & \multicolumn{2}{c}{ Simulated } & & \multicolumn{2}{c}{$\begin{array}{c}\text { Percent change } \\
\text { from observed }\end{array}$} \\
\cline { 2 - 6 } & $\begin{array}{l}\text { P1an A } \\
\left(\mathrm{ft}^{3} / \mathrm{s}\right)\end{array}$ & $\begin{array}{c}\text { Plan B } \\
\left(\mathrm{ft}^{3} / \mathrm{s}\right)\end{array}$ & $\begin{array}{c}\text { Observed } \\
\left(\mathrm{ft}^{3} / \mathrm{s}\right)\end{array}$ & $\begin{array}{l}\text { P1an A } \\
\left(\mathrm{ft}^{3} / \mathrm{s}\right)\end{array}$ & $\begin{array}{c}\text { Plan B } \\
\left(\mathrm{ft}^{3} / \mathrm{s}\right)\end{array}$ \\
\hline $\mathrm{Q}_{7,2}$ & 1,300 & 1,500 & 1,600 & -19 & -8 \\
$\mathrm{Q}_{7,10}$ & 810 & 1,000 & 900 & -10 & +12 \\
\hline
\end{tabular}




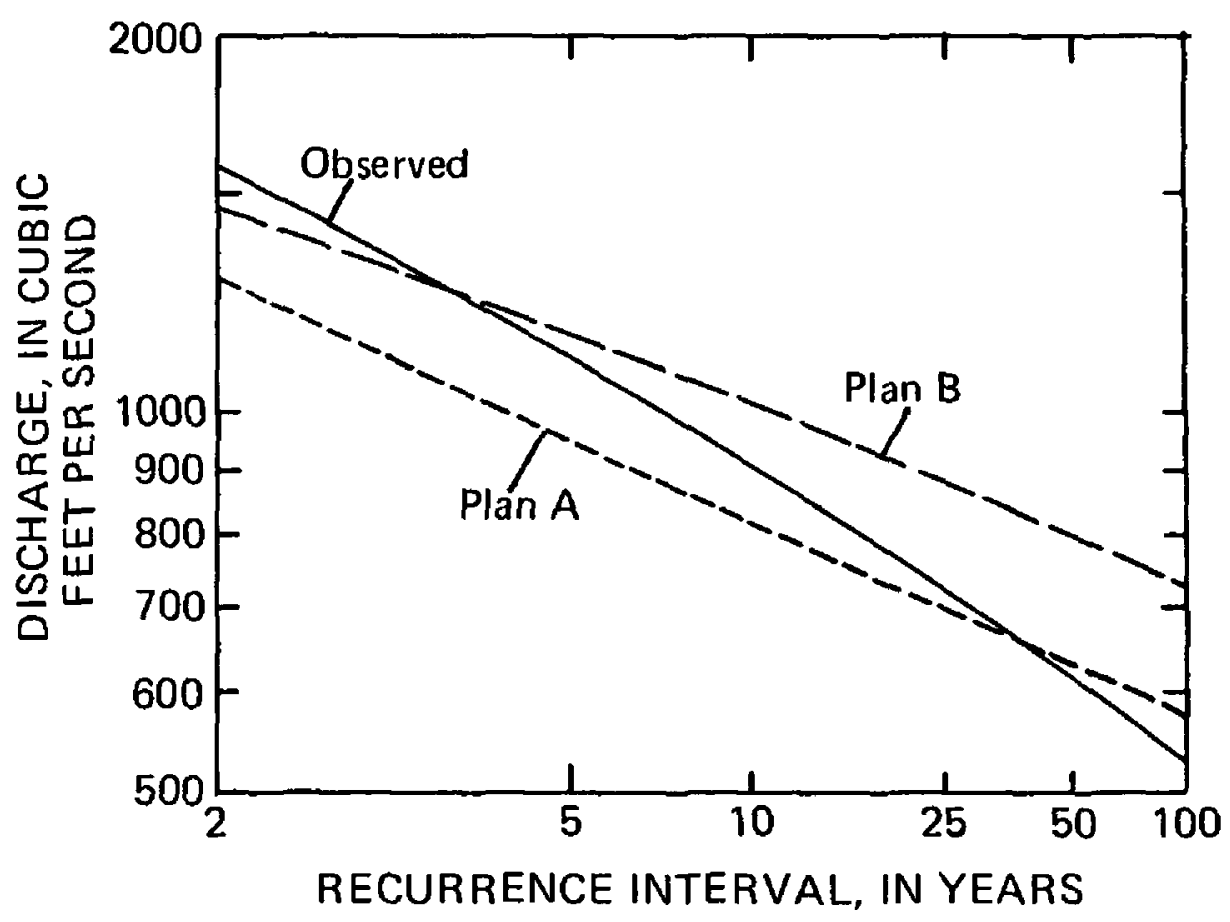

Figure 6. Comparison of 7-day, low-flow frequency curves for the Fox River near Wrightstown (04084500) for water years 1918-78.

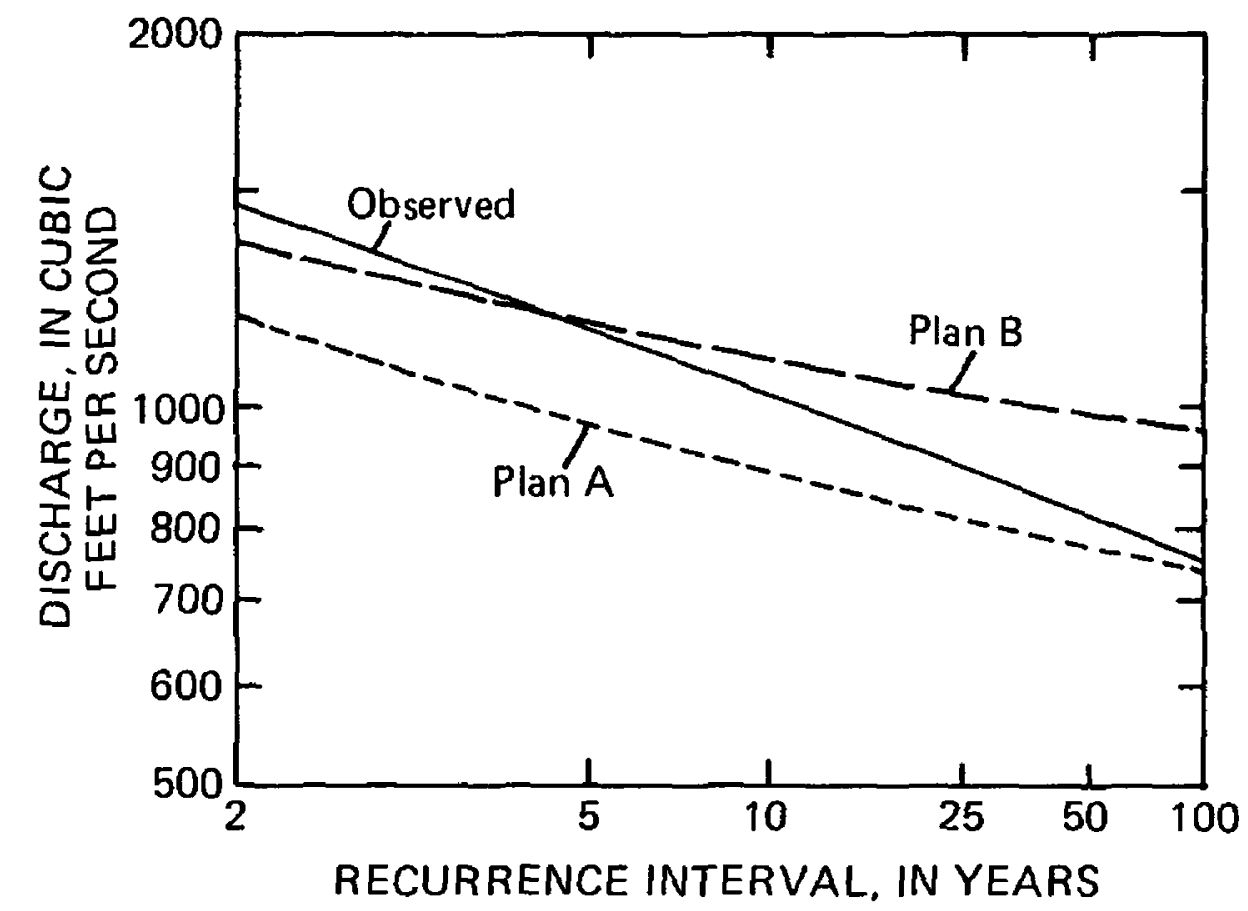

Figure 7. Comparison of 7-day, low-flow frequency curves for the Fox River near Wrightstown (04084500) for water years 1948-78. 
Seven-day, low-flows were also computed for each month of the year. The Q7,10 for the May-October months are compared in the following table. The Q7,10 for a month is the minimum 7-day average flow during the month, below which the flow will fall on the average every 10 years.

Comparison of simulated and observed $Q_{7,10}$ for summer and fall months

\begin{tabular}{lrcccc}
\hline & \multicolumn{2}{c}{ Simulated } & & \multicolumn{2}{c}{$\begin{array}{c}\text { Percent change } \\
\text { from observed }\end{array}$} \\
\cline { 2 - 3 } & $\begin{array}{l}\text { Plan A } \\
\left(\mathrm{ft}^{3} / \mathrm{s}\right)\end{array}$ & $\begin{array}{c}\text { Plan B } \\
\left(\mathrm{ft}^{3} / \mathrm{s}\right)\end{array}$ & $\begin{array}{c}\text { Observed } \\
\left(\mathrm{ft}^{3} / \mathrm{s}\right)\end{array}$ & $\begin{array}{c}\text { P1an A } \\
\left(\mathrm{ft}^{3} / \mathrm{s}\right)\end{array}$ & $\begin{array}{c}\text { P1an B } \\
\left(\mathrm{ft}^{3} / \mathrm{s}\right)\end{array}$ \\
\hline May & 1,200 & 1,600 & 2,200 & -45 & -27 \\
June & 930 & 1,400 & 1,900 & -51 & -26 \\
July & 1,000 & 1,200 & 1,400 & -29 & -14 \\
August & 930 & 1,100 & 1,100 & -15 & 0 \\
September & 930 & 1,100 & 980 & -5 & +12 \\
October & 1,000 & 1,600 & 1,000 & 0 & +60 \\
\hline
\end{tabular}

The dams at the outlet of Lake Winnebago were modified to increase sluicing capacities in 1938. It seems from historical records that the operating rules for the Winnebago pool water levels may have changed about the same time (Arlin Linde, DNR, written commun., 1979). If so, then comparing observed low-flow values during periods before 1938 with a model that uses the same rules throughout the period 1918-78 may not be valid.

Low-flow frequency curves were computed for the period 1948-78 to determine if the comparisons for the longer period are valid. The frequency curves for this period for observed discharges and for discharges simulated for both versions of the proposed plan are shown in figure 7. Comparing this figure with figure 6, it can be seen that all of the frequency curves for the more recent period (on fig. 7) are higher than those on figure 6. This is because figure 7 does not include the period of the 1930's, which included most of the lowest discharges. It is more important to note that the frequency curves lie in the same relationship to each other on both graphs. This indicates no significant error in using the full 61 years of simulated record to show the effect that implementing the proposals would have on Iow flows. The conclusion that Plan B produces higher low flows than the present operating rules is valid both for the entire period simulated and for the last 31 years.

\section{Changes in flood peaks}

One-day high-flow frequency curves were computed from both the simulated and observed records for the Fox River near Wrightstown. The frequency curves are shown in figure 8 . The simulated high flows are slightly less than the observed high flows for the larger flood discharges. Operation Plan B simulated by the model slightly reduces flood hazard on the lower Fox River. 


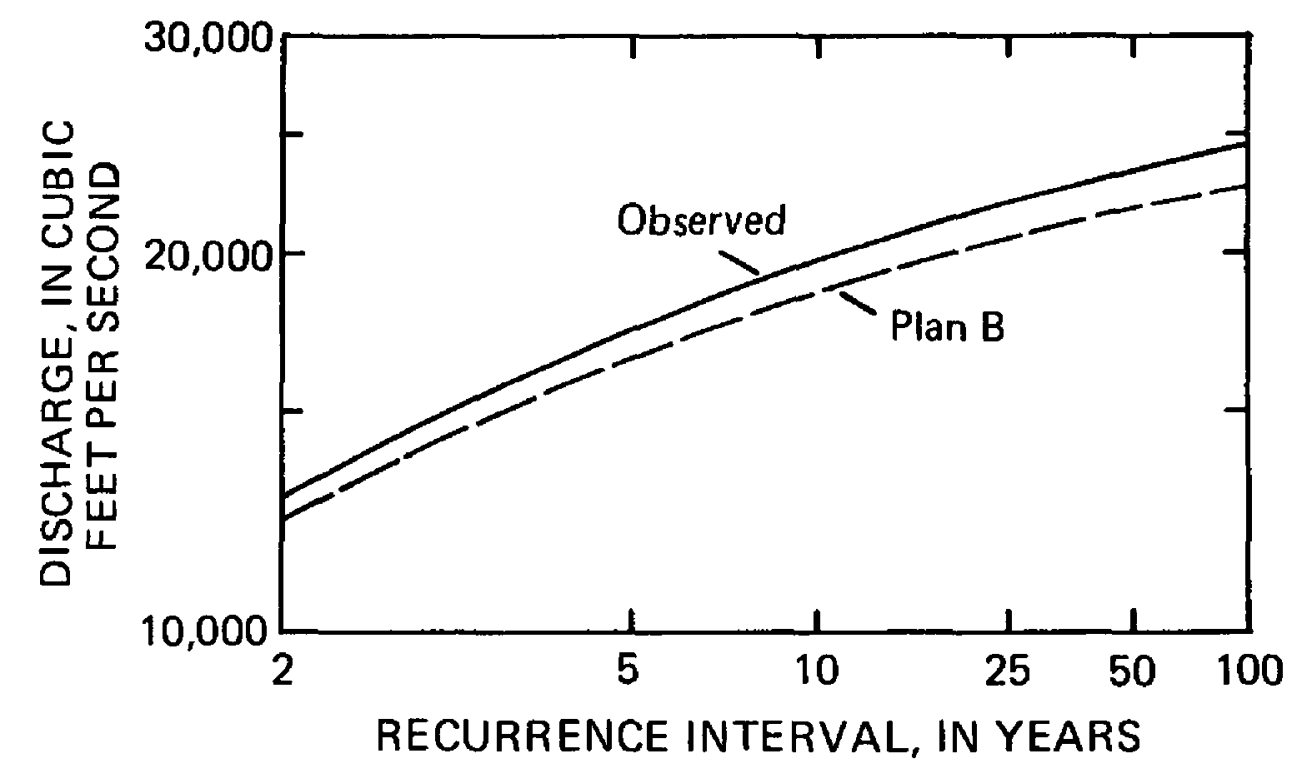

Figure 8. Comparison of high-flow frequency curves for the Fox River near Wrightstown (04084500).

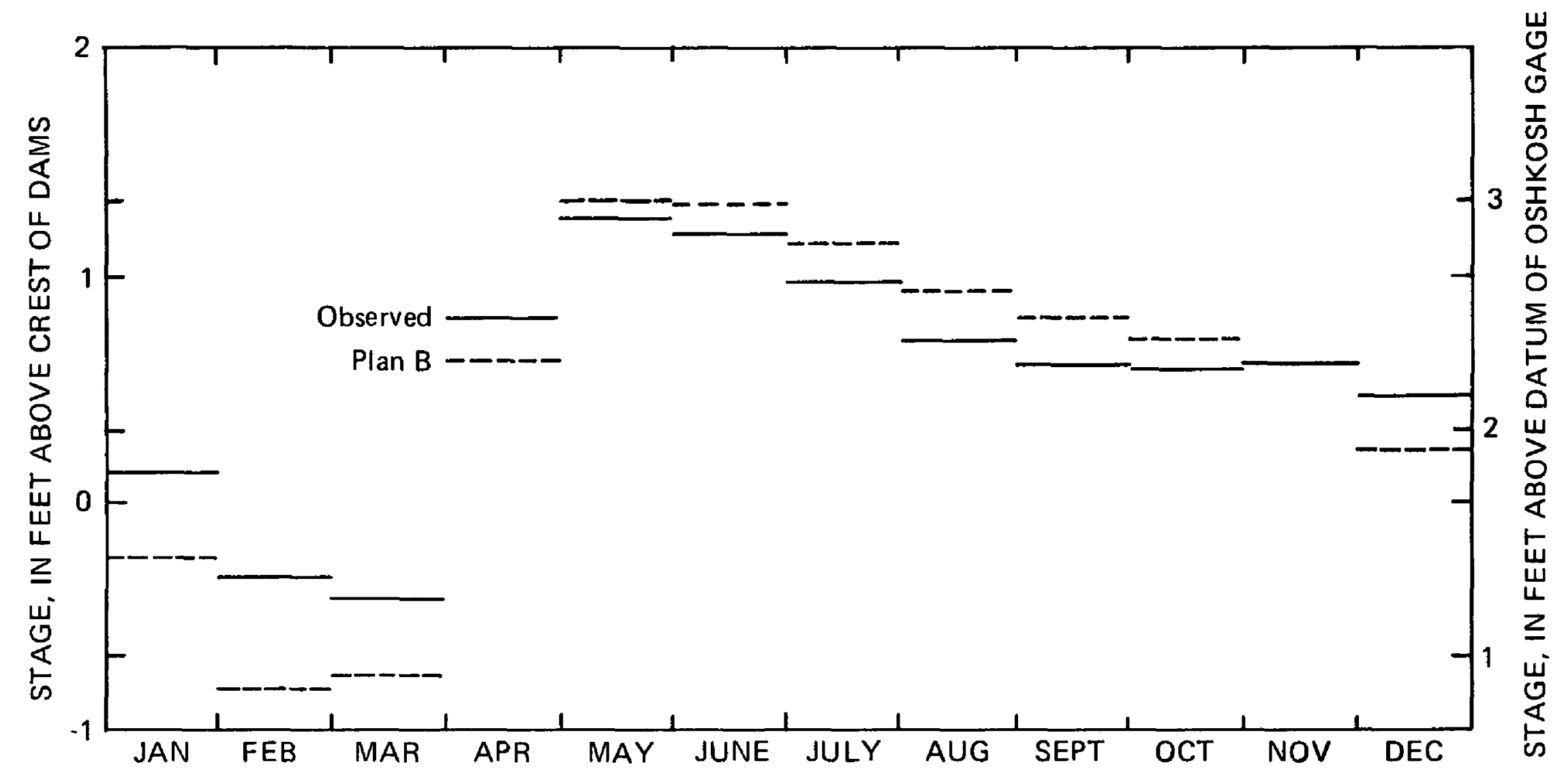

Figure 9. Comparison of mean monthly stages of the Winnebago pool for water years 1918-78.

\section{Changes in stage}

Simulated mean monthly stages of the Winnebago pool for the proposed operation plans were different than the actual mean monthly stages for the same period. These differences were goals of the plans. Figure 9 compares the 
actual mean stages with simulated mean monthly stages for Plan B. The most notable difference is that Plan B causes lower stages during the winter-especially February and March. This is a main goal of the proposa1--to reduce the stage during winter to reduce the amount of ice accumulating in the wetlands. The stage, in April, under the proposed operations is also lower than observed stages-reflecting a delay in filling the pool to prevent damage to the wetlands. Through the navigation season (May through October), the proposed operations caused higher simulated stages than observed stages on the average.

Simulated pool stage for Plan B is compared to observed pool stage for two recent years in figure 10. The first year, 1973, was one of the wettest in recent years, and 1976 was one of the driest years in the entire record. These graphs indicate that the differences in stage are normally not very large. In general, the simulated stage is lower than the observed stage during the wet year and higher than observed stage during the dry year.

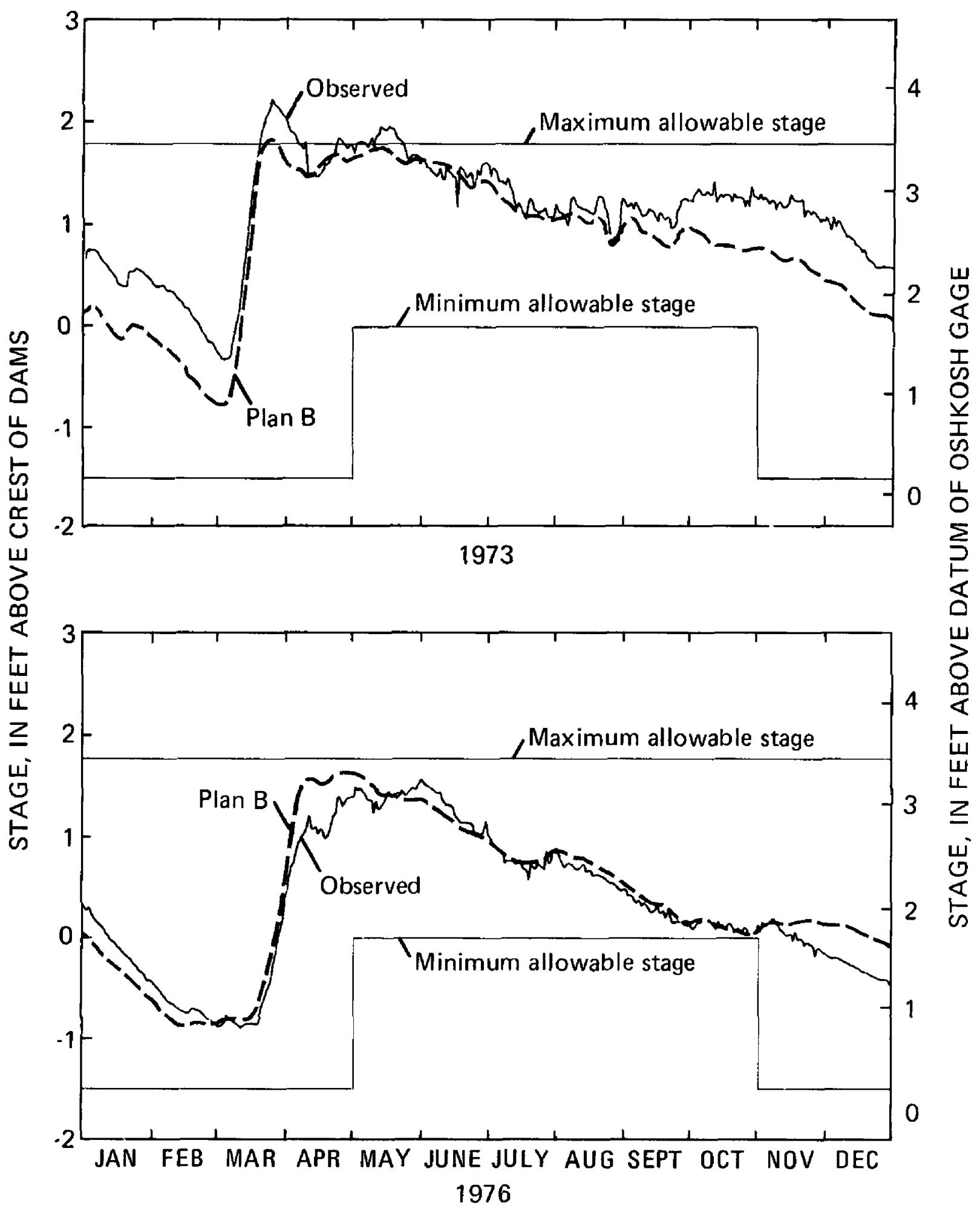

Figure 10. Comparison of observed stage of the Winnebago pool with stage simulated for Plan B for two recent years, one very wet (1973), and the other very dry (1976). 


\section{Reduction in maximum stage}

During large floods, the stage of the Winnebago pool exceeds the maximum allowable. This cannot be prevented completely because the dams have inadequate capacity to pass large floods without exceeding the stage limit. However, the proposed operation plans will reduce the number of days when the stage exceeds the maximum allowable. During 10 of the 61 years included in this study, the observed stage has been higher than the maximum allowable, for a total of 206 days. The simulated stage for Plan B exceeded the maximum allowable in 9 years out of 61 , for a total of 138 days. These totals are probably influenced by the fact that additional gates were added to the dam at Menasha in 1938. Before that time, the dam was less able to pass floodwaters. Since that addition to the dam, the observed stage exceeded the maximum allowable in 6 years out of 40, for a total of 110 days. During the same period, the simulated stage for Plan B exceeded the maximum allowable in 5 years out of 40 , for a total of 68 days.

The simulated stage exceeds the maximum allowable less frequently than does the observed stage, mainly because the simulated stage is normally lower than the observed stage in winter. The proposed plans call for lower stages in winter than have been observed in the past. Because the simulated stage is lower than the observed stage at the start of spring runoff, the highest stage is reduced by a corresponding amount. This can be seen in figure 10, which shows a comparison of observed and simulated stage for 1973. In this year, the maximum observed stage was $0.41 \mathrm{ft}$ above the maximum allowed. For the same year, the maximum simulated stage for Plan B was $0.09 \mathrm{ft}$ above the maximum allowed. The simulated peak stage was lower than the observed peak because the simulated stage was lower in late winter before the start of runoff.

\section{Feasibility of implementing the proposed plans}

Exact duplication of the simulation in practice would require frequent changes in gate openings and partial gate openings (which are not used now). However, such detailed operation is not required to approximate the simulation. First, it is only necessary to adjust gates so that the daily flow is equal to that simulated by the model. In addition, rather large inaccuracies in setting the outflow have small effects on stage. For example, if actual operations produced an outflow that differed from the simulation by $1,000 \mathrm{ft} 3 / \mathrm{s}$ for 7 days, the difference in stage as a result would be less than 1 inch. Based on the rating curves provided by the Corps of Engineers (written commun., 1979), opening one of the six gates on the Menasha Dam would increase the discharge by less than $1,000 \mathrm{ft}^{3} / \mathrm{s}$. The gates at the Neenah Dam have smaller capacities (Ross Plainse, Corps of Engineers, oral commun., 1979). Thus, it seems that the simulation could be adequately duplicated through full gate openings, with adjustments less often than daily, except when stage or inflow are changing rapidly.

\section{RESULTS OF PROPOSED OPERATION PLAN C}

\section{Maintaining minimum discharge}

The model was used to estimate the effects of Plan $\mathrm{C}$ in managing the pool levels to maintain specified levels of discharge in the lower Fox River during dry periods. The model for Plan $\mathrm{C}$ is a modification of the model for Plan B; it simulates pool drawdown to meet specified levels of low flow. Daily discharge 
was computed as before; then, if the computed discharge was less than the specified flow, the specified flow was substituted in the calculations as the outflow. Five levels of minimum flow were simulated $(1,100,1,200,1,300$, 1,400 , and $\left.1,500 \mathrm{ft}^{3} / \mathrm{s}\right)$.

During most of the years included in the simulation, the modification had no effect, because discharge, as computed in Plan B, was always above the specified levels. In other years, the modifications did affect discharge, but the differences were so small and of such short duration that differences in stage were too small to be measured. In a few years, the modifications caused measurable changes in stage.

To estimate the effect of the pool drawdown trials separately from other effects, the stages computed by the model, including flow augmentation ( $\mathrm{Plan} \mathrm{C}$ ), were compared with the stages computed by the model with no flow augmentation (Plan $B)$. The following table shows the number of years and percentage of time (out of 61 years simulated) in which the difference in stage caused by flow augmentation exceeded 1 and 6 inches.

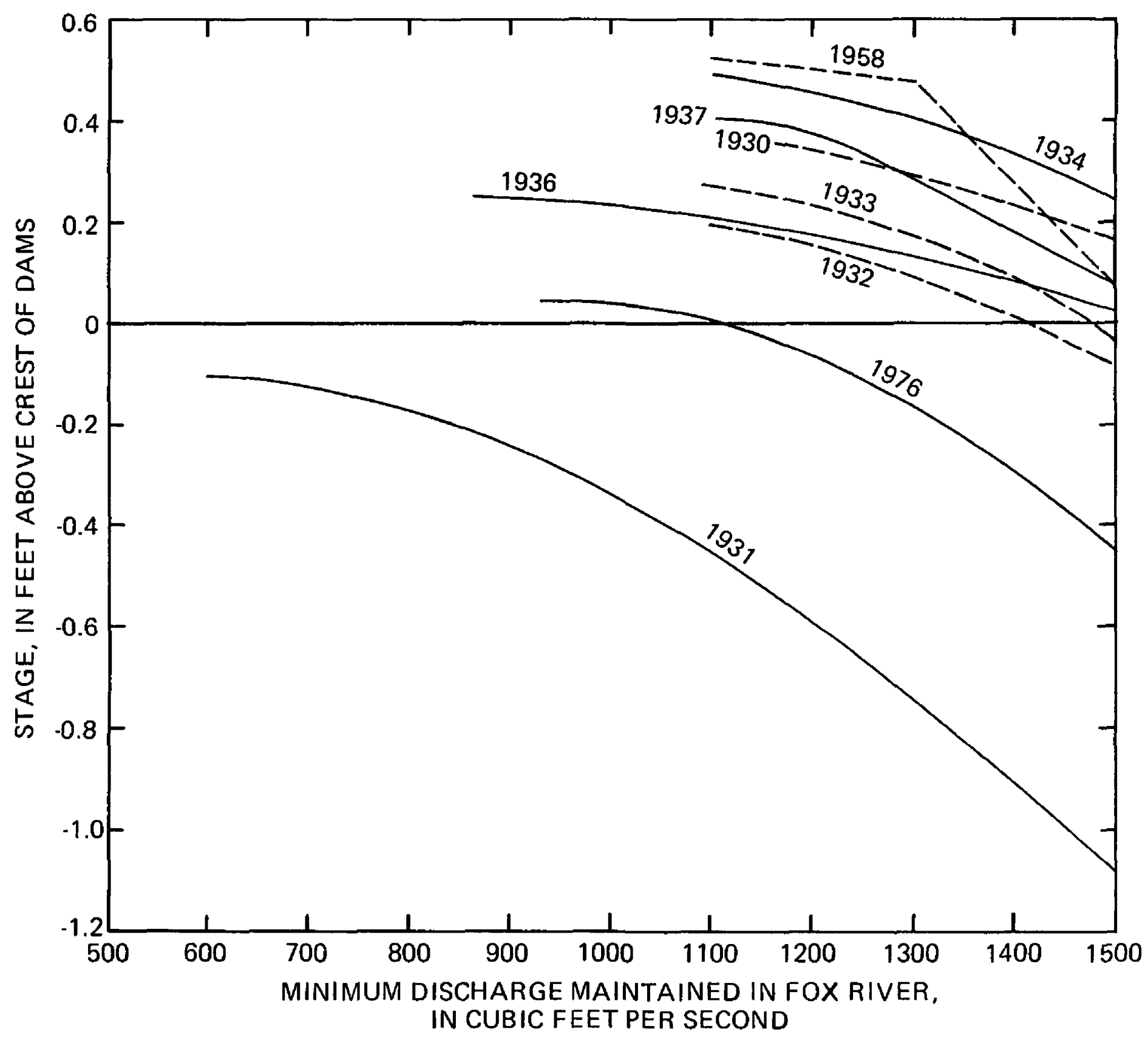

Figure 11. Lowest stage during navigation season for various levels of minimum discharge maintained in the Fox River. 
Difference in stage between Plan B and

Plan C greater than:

\begin{tabular}{cccccc} 
Minimum discharge & \multicolumn{2}{c}{1 inch } & \multicolumn{2}{c}{6 inches } \\
\cline { 2 - 4 } $\begin{array}{c}\text { Number } \\
\text { of years }\end{array}$ & $\begin{array}{c}\text { Percent } \\
\text { of time }\end{array}$ & $\begin{array}{c}\text { Number } \\
\text { of years }\end{array}$ & $\begin{array}{c}\text { Percent } \\
\text { of time }\end{array}$ \\
\hline 1,100 & 1 & 0.74 & 0 & 0 \\
1,200 & 3 & 1.22 & 1 & 0.22 \\
1,300 & 9 & 2.54 & 1 & 0.42 \\
1,400 & 10 & 4.61 & 1 & 0.55 \\
1,500 & 18 & 6.62 & 2 & 0.90 \\
\hline
\end{tabular}

There are two other significant factors in considering drawdown caused by flow augmentation. They are the magnitude of drawdown in any year and whether the stage would go below the dam crest during the navigation season. Figure 11 illustrates both of these factors for the 9 years of lowest stage out of the 61 years simulated. This figure is a graph of the lowest stage during the navigation season for the various levels of flow augmentation. Note that for 1 year (1931--during a severe drought) the stage was below the crest even without flow augmentation. For flow augmentation between 1,100 and $1,400 \mathrm{ft} 3 / \mathrm{s}$, only 2 years out of 61 would have any days with stage below the dam crest.

\section{SUMMARY}

Two types of changes in the operation of the Winnebago pool have been proposed by DNR and FVWQPA. The first involves changing the timing and degree of changes in stage through the year, within the present regulatory constraints on stage. The second involves releasing water from the pool to maintain specified levels of minimum discharge in the Fox River. In the first case, there were concerns that the changes might reduce low flows in the Fox River. In the second case, there were concerns that the changes might lower the water level in the pool below the regulatory minimum stage or below the stage that would occur under the current operating rules.

A digital model of the Winnebago pool was used to simulate the results of proposed changes in the operations of the water levels in the pool lakes. The model was used to simulate stages and flows for two versions of proposed operations for water years 1918-78, Plans A and B. It was also used to simulate the effects of managing the pool levels to assure that flow in the Fox River downstream would not fall below a specified discharge, Plan C. Five different levels of discharge were tried $\left(1,100,1,200,1,300,1,400\right.$, and $\left.1,500 \mathrm{ft}^{3} / \mathrm{s}\right)$.

Plan $A$ is the original version of a proposal designed for wetland preservation. It involved delaying the fall drawdown and the spring refilling of the pool. It caused simulated low flows in the Fox River to be reduced below what has been observed under current operations. The $Q_{7}, 10$ was reduced from 900 to $810 \mathrm{ft} 3 / \mathrm{s}$, and the $Q_{7,2}$ was reduced from 1,600 to $1,300 \mathrm{ft}^{3} / \mathrm{s}$. 
Plan $B$ was developed to attempt to raise the simulated low flows without sacrificing the wetland-preservation goals of the operation plan. It followed the same outline as Plan A, but completed the winter drawdown earlier and allowed the pool to fill to its spring maximum elevation as soon as the ice broke up. The simulated low flows with this version were higher. The $Q 7,10$ was raised to $1,000 \mathrm{ft} 3 / \mathrm{s}$ (12 percent greater than the observed), and the $Q_{7}, 2$ was raised to $1,500 \mathrm{ft} 3 / \mathrm{s}$ ( 8 percent lower than the observed). This plan still had the desired changes in stage, including lower stages in winter and early spring, a delayed filling of the pool, and slightly higher water levels in the summer.

The model for Plan C was adapted from Plan B to simulate the use of water in the Winnebago pool when necessary to guarantee that specified levels of discharge will always be maintained in the lower Fox River. In more than half of the 61 years simulated, there were no changes in simulated discharge or lake stage because the discharge was always above the desired levels. Maintaining a discharge of $1,200 \mathrm{ft} 3 / \mathrm{s}$ would have lowered the stage of the pool by more than 1 inch in only 3 years of the 61 simulated. Even maintaining a discharge of $1,500 \mathrm{ft}^{3} / \mathrm{s}$ would have lowered the stage by more than an inch in 1 year out of 4. It would have lowered the stage by more than 6 inches in 1 year out of 30 .

While Plans A and B comply with the minimum stage requirements for the pool, Plan $C$, by attempting to maintain a specified discharge, would conflict in a few years with the requirement to keep the lake stage above the dam crest during the navigation season. In the 61 years simulated, there was 1 year when stage was below the dam crest, even without maintaining a specified discharge. Maintaining discharge of $1,200 \mathrm{ft}^{3} / \mathrm{s}$ would have violated the minimum stage standard in 1 additional year. Maintaining $1,500 \mathrm{ft} 3 / \mathrm{s}$ would have violated the minimum stage standard in a total of 4 years.

Plan $B$ could be adopted without seriously reducing the low flows in the Fox River downstream from the Winnebago Pool. Low flows with a recurrence interval greater than about 5 years would be increased. This proposed operation plan would also succeed in changing the stages of the Winnebago pool in ways that are expected to protect the wetlands adjacent to the pool lakes.

A preliminary investigation of the effect of errors caused by actual operations that differ from the simulation showed that the simulation could be approximated reasonably well in practice. Actual operations that differed from the simulation by one full gate opening for 7 days would cause a stage difference of less than 1 inch.

\section{REFERENCES}

Keefer, T. N., 1974, Desktop computer flow routing: American Society of Civil Engineers, HY1, Proceedings Paper 10669, p. 1047-1058.

Sauer, V. B., 1973, Unit-response of open-channel flow routing: American Society of Civil Engineers, HY1, Proceedings Paper 9499, p. 179-193. 